doi: $10.18575 /$ msrs.sm.e. 17.19

UDC 616.441-008.64-08:546.23 COBISS.RS-ID 6836504

\section{Reliability of Targeted Surgical Approach in the Treatment of Primary Hyperparathyroidism}

\begin{abstract}
Introduction: It is estimated that the prevalence of primary hyperparathyroidism in patients over 40 years is about $1 \%$ (men $0.4 \%$, women $1.6 \%$ ). Despite developments in diagnosis today, the highest percentage of patients with hyperparathyroidism remains undetected, and it is estimated that only $10 \%$ of cases are diagnosed and treated. In $90 \%$ of patients, the cause of hyperparathyroidism is one pathologycally changed parathyroid gland.
\end{abstract}

Aim of the Study: To estimate the efficiency and reliability of a conservative approach in surgical treatment, previously diagnosed with primary hyperparathyroidism, in comparison to a traditional neck exploration showing all four parathyroid glands.

Patients and Methods: In the study, we analyzed the results of 71 patients at the University Clinical Center of the Republic of Srpska in the period from 2008 to 2017. The diagnosis of primary hyperparathyroidism was set based on the ultrasonography and scintigraphy of parathyroid glands, neck CT scan, clinical pictures and laboratory findings. The surgery included short cervical incision of 2 $\mathrm{cm}$ and $4 \mathrm{~cm}$, placed $2 \mathrm{~cm}$ above the jugulum with unilateral neck exploration and extirpation of modified parathyroid gland.

Results: In the research were used classification methods, structural - functional analysis, synthesis, comparisons, abstractions, concretisations and simpler statistical method with the use of descriptive statistics to prove the hypothesis set, out of which tables, grafs, and summaries were used. 71 patients diagnosed with primary hyperparathyroidism were operated. The youngest patient was 28-year-old and the oldest 79-year-old. On the basis of the $\mathrm{PH}$ findings, targeted parathyroidectomy procedure was successful in $94.3 \%$ cases.

Conclusion: The goal of the surgical approach, with unilateral neck exploration, allows successful identification of pathologically modified parathyroid gland and efficient treatment of primary hyperparathyroidism.

Key words: Primary hyperparathyroidism, parathyroidectomy, conserving surgical approach, unilateral neck exploration

(Scr Med 2017:48:131-136)
Dušan Janičić ${ }^{1}$, Slavko Grbić, Ljiljana Krupljanin ${ }^{1}$, Božo Krivokuća ${ }^{2}$, Marko Kantar

${ }^{1}$ Clinic of Thoracic Surgery, UCC Banja Luka

2 Clinic for General and Abdominal surgery, UCC Banja Luka

Contact address:

Janičić Dušan

UCC RS

Street address: Zdrave Korde br 1 $780 o o$ Banja Luka,

Republic of Srpska

Bosnia i Herzegovina

e-mail: dusan.janicic@gmail.com phone number: +387-65-522-870

Submitted: June $26^{\text {th }}, 2017$ Accepted: August 18 ${ }^{\text {th }}, 2017$ 


\section{Introduction}

It is estimated that the prevalence of hyperparathyroidism in patients over 40 years is about $1 \%$ ( about 0,4 in men $\%$, and $1.6 \%$ in women). And despite developments in diagnosis, the highest percentage of patients with hyperparathyroidism remains undetected, and only about $10 \%$ of cases are diagnosed and treated. In 90 $\%$ of cases, the cause of hyperparathyroidism is one pathologically modified parathyroid gland. ${ }^{1-3}$

Primary hyperpathyroidism is a disease of a parathyroid gland which is characterised by disproportionately excessive secretion of parathyroid hormone which exceeds the psyhological reguirements and physiological frames of calcium level in a serum. Two essential characteristics are the increased mass of the functional parathyroid cells and their disfunction.

Primary hyperpatahyroidism occurs as a hereditary disease as the part of multiple endocrine neoplasia, or as a sporadic disease.

Patho - anatomical substrate of the primary hyperparathyroidism is adenom ( $80 \%$ ), hyperplasia ( 16 $\%$ ), or carcinoma $(0.5-5 \%) .{ }^{1-3}$

\section{Aim of the Study}

The aim of the study is to estimate the efficiency and reliability of a conservative approach in surgical treatment, previously diagnosed with primary hyperparathyroidism, in comparison to a traditional neck exploration showing all four parathyroid glands.

\section{Patients and Methods}

The data needed for the study were collected from medical histories, operational protocols and on the basis of definite histopathological postresection findings, performed at the Department of Pathology, University Medical Center RS Banja Luka, which minimally contained a description of the removed changes in terms of adenoma or hyperplasia of the parathyroid glands, and the description in terms of some other changes. In the study, we analyzed the results of 71 patients at the University Clinical Center of the Republic of Srpska in the period from 2008 to 2017.

Indications for surgical treatment of primary hyperparathyroidism were as follows:

hypercalcemia in all patients under fifty years of age; hypercalcemia greater than $3 \mathrm{mmol} / \mathrm{l}$ in all age groups; symptomatic calcemia in all age groups; renal function impairment; osteopenia; Calciuresis (more than 400mg /
24 hours); suspected carcinoma of the parathyroid gland.

The diagnosis of primary hyperparathyroidism was based on the ultrasonography, and scintigraphy parathyroid gland, CT of the neck, clinical pictures and laboratory findings.

The condition for operative treatment was the reduction of calcimum level in the serum reduced to below 3.1 mmol / l. Renal function was checked preoperatively, patients were rehydrated with calcium-free solutions and catheterisation was performed in order to monitor diuresis. Preoperative diuretic was administered to increase the excretion of calcium through the kidneys; antiemetic and $\mathrm{H} 2$ blocker. Level of potassium in the plasma was controlled and eventual hypokalemia was corrected, as well as the ECG preoperatively. In order to locate a pathologically modified parathyroid gland, all patients underwent SPECT and planar scintigraphy of the parathyroid gland, with Tc - $99 \mathrm{~m}$, as well as ultrasonography and CT of the neck. ${ }^{1}$

The surgery included short cervical incision of $2 \mathrm{~cm}$ and $4 \mathrm{~cm}$, placed $2 \mathrm{~cm}$ above the jugulum. Unilateral exploration of thyroid lodges was performed in terms of detecting and extirpating of the modified parathyroid gland. If necessary, a lobe of the thyroid gland was mobilized and rotated forward and medially with the pre-ligation and cutting of the middle thyroid veins. Dissection was performed with the thyroid capsule, according to the finding which pointed to the altered lower or upper parathyroid gland. If additional thyroid gland lobe mobilization was required, a superior thyroid artery was ligated to the exploration of the upper aspect of the thyroid lodge.

Evaluation of the efficiency of the target surgical approach and the results in the treatment of primary hyperparathyroidism was divided into groups based on the definitive $\mathrm{PH}$ finding, the number of removed parathyroid glands, duration of the procedure and postoperative.

\section{Results}

Of the generals methods, in the research were used classification methods, structural - functional analysis, synthesis, comparisons, abstractions, concretisations and simpler statistical method. The specificity and scope of the research incited the use of descriptive statistics to prove the hypothesis set, out of which tables, grafs, and summaries were used. A collection, processing and presentation of data were combined with inferential statistics, that is, with the determination and observation of the characteristic sample as the part of a set of units, in 
order to reach a conclusion on the whole set.

A case study was selected to be the basic method of research. In the first phase, this method involved the collection of data on selected examples from practice, as concrete individual events associated with a particular set of common features. The objectivity and reliability of the case study method was provided by selecting the subject of research as a unique system, with a significant contribution and use of the practical experience of researchers in this field. Case studies, as a rule, represent an adequate choice in situations of insufficient theoretical and practical knowledge of a particular phenomenon or process, and when there is no generally accepted model of behaviour.

71 patients diagnosed with primary hyperparathyroidism were operated. The youngest patient was 28 years old and the oldest 79 years old. The surgery was performed in 67 women and four men. The average age of patients was 58.55 years. The average age of the operated women was 58.91 years. The average age of operated men was 53 years (Table 1.)

Table 1. The average age of operated patients

\begin{tabular}{cccc} 
Patients & Number & Percentage & Average age \\
\hline Women & 67 & $94.36 \%$ & $\begin{array}{c}58.91 \\
\text { years }\end{array}$ \\
\hline Men & 4 & $5.63 \%$ & $\begin{array}{c}53 \text { years } \\
\text { Total }\end{array}$ \\
& 71 & $100 \%$ & $\begin{array}{c}58,55 \\
\text { years }\end{array}$ \\
\hline
\end{tabular}

In terms of removal of one parathyroid gland, parathyroidectomy was done in 69 cases (97.18\%); while in terms of removal of both parathyroids, parathyroidectomy was performed in two patients (2.81\%) - Table 2.

Table 2. Type of surgical procedure

\begin{tabular}{lcc}
\multicolumn{1}{c}{ Surgical procedure } & $\begin{array}{c}\text { Number of } \\
\text { operated }\end{array}$ & Percentage \\
\hline $\begin{array}{l}\text { Single } \\
\text { parathyreoidectomy }\end{array}$ & 69 & $97.18 \%$ \\
$\begin{array}{l}\text { Double } \\
\text { parathyreoidectomy }\end{array}$ & 2 & $2.81 \%$ \\
Total operated & 71 & $100 \%$ \\
\hline
\end{tabular}

On the basis of PH findings, targeted parathyroidectomy procedure was successful in $94.3 \%$ cases. Hyperplasia of the parathyroid glands was detected in 14 operated patients $(19.71 \%)$; adenomas in 53 patients surgically treated (74.64\%) and the other pathohistological findings in four patients, that is, in $5.63 \%$ (in one patient the parathyroid tissue was without morphological changes, in a single patient $\mathrm{PH}$ finding detected the node in the thyroid gland, and in two patients the resected tissue did not contain parathyroid gland tissue. (Chart 1)

Chart 1. Successful application of surgical procedure based on pathohistological findnigs

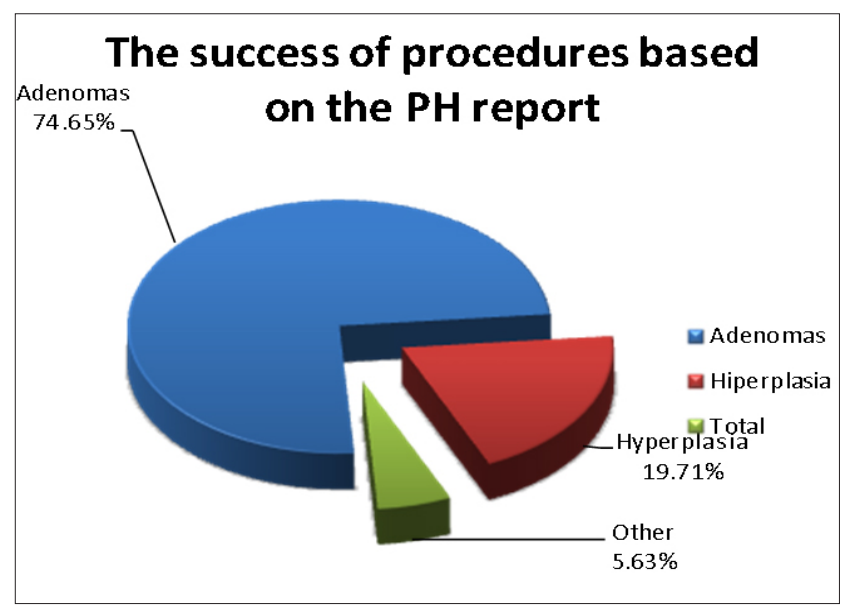

The average duration of surgery was 25 minutes. Surgical procedures were performed in OEA. The length of hospitalisation was two days. Patients were discharged to home care on the second postoperative day. Ionogram was performed postoperatively.

Postoperative complications were not observed.

\section{Discussion}

Diagnosis of primary hyperparathyroidism requires a minimum of the detection of elevated levels of total calcium in the serum, with an increased level of PTH. Preoperatively, the vitamin D deficit should be excluded. Contraindication for surgical treatment are patients with familial hypocalciuric hypercalcemia (FHH). Most patients with primary hyperparathyroidism are asymptomatic; 10 to $20 \%$ of patients have nephrocalcinosis, and only a few osteitis fibrosa..$^{1-2}$ The most common indication for primary surgical treatment of primary hyperparathyroidism in the UCC RS, from 2008 to 2017 was a pathologically modified parathyroid gland. The ratio between women and men in our series was significantly different from the one in the literature, where this ratio was 2:1 (in our patients the ratio of 
women - men was 17: 1).

The goal of surgical treatment is to remove abnormal parathyroid tissue and preserve a normal one. Perfect result is a normal calcium level in the serum, normal PTH level, unchanged voice and discreet or invisible scar. The first operation is a "golden opportunity" for hyperparathyroidism to be corrected successfully. ${ }^{3}$ During the parathyroid surgery, opening of the capsule and local implantation of parathyroid cells should be avoided, as it causes relapses that can hardly be corrected by reoperation.

The traditional approach in surgery of primary hyperparathyroidism is the exploration of all four parathyroid glands and removal of enlarged and pathologically altered parathyroid gland. ${ }^{1-3}$ Given that in about $80 \%$ of cases, the cause of primary hyperparathyroidism is adenoma or hyperplasia of one of the four parathyroid glands, the targeted access to an amended, preoperatively identified parathyroid gland,with small incision is a rational approach. Patients treated in this way have shorter periods of hospitalisation, and surgery can be performed in regional anaesthesia. In the series of operated patients, surgeries were not done under regional anesthesia, and the average length of hospitalization was two days, which is two days shorter when compared to the traditional surgical approach with exploration of all four parothyroid glands.

When localizing pathologically modified parathyroid gland, preference is given to an essentially planar and SPECT scintigraphy of the parathyroid glands, with Tc $99 \mathrm{~m}$, for which the accuracy is about 93\%, as compared to CT and ultrasonography of the neck, which proved to be a useful supplementary method when the MIBI scan shows a negative results.1-3All operated patients underwent SPECT scintigraphy at the Department of Nuclear Medicine of UCC RS. Only two patients were suspected of the existence of double adenoma parathyroid gland. Based on the SPECT scintigraphy findings, two parathyroid glands were removed, but there was no pathohistologically confirmed double adenoma existence.

In $91 \%$ of cases, the cause of hyperparathyroidism is one pathologically modified parathyroid gland..$^{1-4}$ Therefore, the key moment in the operative treatment of hyperparathyroidism is for the surgeon to locate and extirpirate the modified parathyroid gland, which, considering the anatomical variations and the nature of process is not always a simple procedure..$^{3-4}$ Pathological lesions responsible for the onset of the primary hyperpatahyrodism are as follows: solitary adenoma (80 - $91 \%)$, multiple hyperplasia of the parathyroid gland
(15\%), and very rarely cancer of the parathyroid gland. ${ }^{2}$ It is extremely important that the surgeon preoperatively knows which and how many parathyroid glands are pathologically changed. Some of the papers suggest the occurrence of double adenoma in $4 \%$ of cases of hyperparathyroidism. ${ }^{2}$ Parathyroid cysts are extremely rare and are usually diagnosed as masses on the neck (they are mostly non-functional, and only $10-15 \%$ lead to hyperparathyroidism). ${ }^{2}$ Also, oxyphil parathyroid glands adenomas, (although diagnosed as pathological changes ), in most cases are non-functional. ${ }^{3-4}$

If we compare our results with reports in the literature, it can be noticed that the presence of parathyroid adenoma was not so frequent (75 \%), presence of hyperplasia of parathyroid glands was more frequent( about 20 $\%$, while we did not have cases of double adenoma of parathyroid glands.

The average age of our examined group, in thetotal number of operated amounts to 58.55 (men 53 , and women 58.91) years, which resulted in the conclusion that patients with diagnosed and treated primary hyperparathyroidism, in most cases, were in the sixth decade of life; that is, 54 patients $(76.06 \%)$ were older than 50 . These results are consistent with reports in the literature, according to which primary hyperparathyroidism disease affects the sixth decade. ${ }^{5-6}$ Parathyroidectomy is indicated in all patients with symptoms, whereas in asymptomatic image in all young people and in all others with renal disfunction, osteopenia, calcemia larger than 2.85 $\mathrm{mmol} / \mathrm{l}$ and calciuresis over $400 \mathrm{mg} / 24$ hours. $^{5}$

Parathyroidectomy was performed according to the aforementioned indications in a 28 year-old patient, who was also the youngest surgical patient in the patient group shown.Successful, targeted parathyroidectomies, in terms of adenomas and hyperplasia of parathyroid glands were performed in 67 patients (94.3\%, of the cases). In $5.63 \%$ of cases, histopathologic examination revealed that the thyroid gland tissue or lymph node tissue was removed.

The above mentioned results are in line with the ones in literature stating that the efficacy of targeted parathyroidectomy in primary hyperparathyroidism is 94-98\%, compared to the traditional approach, whose efficacy is about $95 \% .{ }^{6,7}$

In the presented series, the cause of primary hyperparathyroidism in 67 patients (94.36\%) was a pathologically modified parathyroid gland. This percentage is somewhat higher than the quotations in published works, where this percentage is about $91 \%$. 
Double parathyroid adenoma in this series was not detected, although in one case, we removed two parathyroid glands on the basis of the previous diagnosis. The prevalence of double adenoma in primary hyperparathyroidism is not clear as yet.

Parathyroid gland carcinoma was not recorded in displayed series. In the case of cancer, the standard was the performance of hemithyroidectomy with lymphadenectomy along with postoperative radiation, aside from parathyroidectomy. ${ }^{5}$

Also, in the above mentioned series of patients we had no adenomas or hyperplasia of parathyroid glands that had been detected preoperatively, undergone surgery and had been localised in the mediastinum.

In the case of hyperplasia of all the parathyroid glands there are two courses of action:

1. The total parathyroidectomy with or without autotransplantation of parathyroid tissue in the nondominant arm (with the high local recurrence due to check the possibilities for implantation of malignant tissue or tissue other than parathyroid)

2. subtotal parathyroidectomy - removal of the three parathyroid glands while maintaining $125 \mathrm{mg}$ of a parathyroid tissue upon histopathological examination.

All displayed patients were operated in general endotracheal anesthesia

Complications following operational procedure are rare: bleeding, infection, injury n.laryngeus reccurens, postoperative unsatisfactory result (persistent hyperparathyroidism), postoperative transient hypocalcemia (no earlier than 24 hours after surgery). Postoperative complications were not reported in the presented series of operated patients, and according to the literature, postoperative complications were rare, about $2 \%{ }^{6,7,8}$

The average duration of the operation - 25 minutes was slightly longer than in the literature (20 min).

\section{Conclusion}

The goal of the surgical approach, with unilateral neck exploration, allows successful identification of pathologically modified parathyroid gland and efficient treatment of primary hyperparathyroidism. The results of this approach are comparable and better than the traditional approach with exploration of all four parathyroid glands.

\section{References}

1. Muhammad Adil Abbas Khan,Sadia Rafiq,Sophocles Lanitis,Farhan Arshad Mirza et al. - Surgical Treatment of Primary Hyperparathyroidism : Description of Techniques and Advances in the Field;Indian Journal Surgery,2014 Aug ;76(4):308-315 https://doi.org/10.1007/s12262-013-0898-o PMid:25278656 PMCid:PMC4175670

2. Sandhya Venkatachala,S Rajesh Kumar,S Premkumar - Double adenoma of the parathyroid : Reinforcing the existence of thisentity; Indian Journal Pathology \& Microbiology, 2013;56:328-9

https://doi.org/10.4103/o377-4929.120420 PMid:24152531

3. Won Woong Kim, Yumie Rhee, Eun Jeong Ban,Cho Rok Lee,Sang-Wook Kang et al - Is focused parathyroidectomy appropriate for patiens with primary hyperparathyroidism?,Annals of Surgical Treatment and Research 2016;91(3):97-103

https://doi.org/10.4174/astr.2016.91.3.97

PMid:27617249

PMCid:PMC5016607

4. Samuel A.,Dowthaite J.,Edward Young,Jesse D.,Pasternak John Yoo _ Surgical Managament of Primary Hyperparathiroidism; Journal of Cilinical Desintometry,Volume 16,Issue 1,January 2013,Pages 4853

5. Philip K.Pellitteri - Surgical management of parathyroid carcinoma,Operative Techniques in OtolaryngologyHead and Neck Surgery,Volume 27,Issue 3,September 2016,Pages 145-151

6. Blair A Williams,Jonathan RB Trites,S Mark Taylor,Martin $\mathrm{J}$ Bullock et al._Surgical management of primary hyperparathyroidism in Canada,Journal of Otolaryngology - Head \&Neck Surgery,2014, 43:44 https://doi.org/10.1186/s40463-014-0044-4 PMid:25367580 PMCid:PMC4221664

7. Chow TL,Choi CY,Lam SH - Focused parathyroidectomy without intra - operative parathyroid hormone monitoring for primary hyperparathyroidism : results in low - volume hospital. - J Laryngol Otol.2015 Aug; 129 (8): 788-94. https://doi.org/10.1017/So022215115000651 PMid:26072937

8. Salem I. Noureldine, Zhen Gooi,and Ralph P. Tufano Minimally invasive parathyroid surgery - Gland Surg.2015 Oct; 4(5): 410-419 


\section{Pouzdanost ciljanog hirurškog pristupa u terapiji primarnog hiperparatiroidizma}

\section{SAŽETAK}

Uvod: Procjenjuje se da je, kod starijih od 40 godina, prevalenca primarnog hiperparatiroidizma oko 1\% (kod muškaraca 0,4\%, a kod žena 1,6\%). Unatoč napretku u dijagnostici, i danas najveći procenat bolesnika sa primarnim hiperparatiroidizmom ostaje neotkriven, te se procjenjuje da se oko 10\% slučajeva dijagnostikuje i liječi. Kod 90\% pacijenata, uzrok primarnog hiperparatiroidizma je patološki izmijenjena jedna paratiroidna žlijezda.

Cilj rada: Procjena efikasnosti i pouzdanosti poštednog pristupa u hirurškom tretmanu, prethodno dijagnostikovanog primarnog hiperparatiroidizma u odnosu na tradicionalnu eksploraciju vrata sa prikazom sve četiri paraštitne žlijezde.

Ispitanici i metode: Studijom smo analizirali rezultate 71 operisanog pacijenta na Univerzitetskom kliničkom centru Republike Srpske u periodu od 2008. do 2017. godine. Dijagnoza primarnog hiperparatiroidizma je postavljena na osnovu ultrasonografije i scintigrafije paratirodnih žlijezda, CT-a vrata, kliničke slike i laboratorijskih nalaza. Hirurški pristup je bila kratka ciljana cervikalna incizija od 2 do $4 \mathrm{~cm}$, plasirana dva centimetra iznad juguluma sa unilateralnom eksploracijom vrata i ekstirpacijom izmijenjene paraštitne žlijezde.

Rezultati: U istraživanju su korištene metode klasifikacije, strukturalno-funkcionalne analize, sinteze, komparacije, apstrakcije, konkretizacije i jednostavnije statističke metode uz primjenu deskriptivne statistike u dokazivanju postavljene hipoteze, od kojih su korištene tabele, grafikoni, i sumarne mjere. Operisan je 71 pacijent sa prethodno postavljenom dijagnozom primarnog hiperaparatiroidizma. Najmlađi pacijent je imao 28, a najstariji 79 godina. Na osnovu PH nalaza, procedura ciljane paratiroidektomije je bila uspješna u 94,3\% slučajeva.

Zaključak: Ciljani hirurški pristup sa unilateralnom eksploracijom vrata omogućava uspješnu identifikaciju patološki izmijenjene paraštitne žlijezde i efikasan tretman primarnog hiperparatiroidizma.

Ključne riječi: primarni hiperparatiroidizam, paratiroidektomija, poštedan hirurški pristup, unilateralna eksploracija vrata 